\title{
PENENTUAN TIPE FLUIDA SUMBER MATA AIR PANASDI KECAMATAN GUNUNG TALANG, KABUPATEN SOLOK
}

\author{
Rahmatul Hidayat, Ardian Putra \\ Laboratorium Fisika Bumi, Jurusan Fisika FMIPA Universitas Andalas \\ Kampus Unand, Limau Manis, Padang, 25163 \\ e-mail:rahda.28@gmail.com,ardhee@fmipa.unand.ac.id
}

\begin{abstract}
ABSTRAK
Telah dilakukan penelitian tentang penentuan tipe fluida mata air panas di Kecamatan Gunung Talang, Kabupaten Solok. Berdasarkan analisis kandungan ion $\mathrm{HCO}_{3}{ }^{-}, \mathrm{SO}_{4}{ }^{2-}$, dan $\mathrm{Cl}^{-}$dengan menggunakan diagram trilinier atau diagram Piper. Pengujian kandungan ion $\mathrm{HCO}_{3}{ }^{-}$menggunakan metode titrasi, pengujian kandungan ion $\mathrm{SO}_{4}{ }^{2-}$ menggunakan metode spektrofotometri dan untuk pengujian kandungan ion $\mathrm{Cl}^{-}$digunakan hubungan nilai konduktivitas listrik dan kandungan ion klorida. Sampel mata air panas diambil dari lima lokasi yang berbeda. Hasil yang didapatkan dari penelitian ini adalah kandungan ion tertinggi dari kelima sumber mata air panas adalah ion sulfat, kemudian bikarbonat dan kandungan terendahnya adalah ion klorida. Dari diagram trilinier dapat disimpulkan bahwa kelima sumber mata air panas di Kecamatan Gunung Talang bertipe air sulfat.
\end{abstract}

Kata kunci : tipe fluida, mata air panas, kandungan ion $\left(\mathrm{HCO}_{3}{ }^{-}, \mathrm{SO}_{4}{ }^{2-}\right.$, dan $\left.\mathrm{Cl}^{-}\right)$

\section{PENDAHULUAN}

Seiring dengan kemajuan zaman, kebutuhan energi semakin meningkat. Saat ini pemasok utama kebutuhan energi di Indonesia adalah energi fosil (minyak dan gas bumi), yang mana energi ini tidak dapat diperbarui dan keberadaannya sudah semakin menipis. Untuk itu, perlu dikembangkan energi alternatif pengganti energi fosil tersebut. Salah satu energi alternatif yang dapat dikembangkan dan dapat diperbarui adalah energi panas bumi (geotermal). Indonesia merupakan negara dengan potensi panas bumi yang sangat tinggi. Dari berbagai sumber didapatkan bahwa Indonesia mempunyai potensi panas bumi sekitar 27.000 MW atau sekitar 40\% panas bumi dunia.

Sumatera terbentuk oleh tatanan tektonik yang kompleks, terdapat banyak aktifitas vulkanisme berupa pemunculan gunung api yang terdapat di sepanjang Sumatera yang diakibatkan oleh tumbukan antar lempeng Indo-Australia dan Lempeng Eurasia yang ada di sebelah baratnya. Banyaknya aktifitas vulkanisme ini yang mengindikasikan bahwa terdapat potensi panas bumi yang sangat besar di Sumatera, salah satunya terdapat di Propinsi Sumatera Barat tepatnya di Kecamatan Gunung Talang, Kabupaten Solok. Manifestasi permukaan daerah ini berupa mata air panas, lapangan fumarola/solfatora, streaming ground (tanah hangat), batuan teralterasi dan letusan freatik (Munandar, 2003).

Untuk mengetahui berapa besar potensi panas bumi di suatu daerah perlu dilakukan evaluasi pada setiap tahap kegiatan, yaitu mulai dari tahap survei pendahuluan, eksplorasi, penilaian kelayakan hingga ke tahap eksploitasi dan saat pemanfaatannya. Salah satu langkah awal yang dilakukan adalah menentukan karakterisasi reservoir panas bumi yaitu penentuan tipe mata air panas yang muncul di permukaan dengan meneliti kandungan ion $\mathrm{HCO}_{3}^{-}, \mathrm{SO}_{4}{ }^{2-}$, dan $\mathrm{Cl}^{-}$di mata air panas tersebut.

Mata air panas yang muncul ke permukaan mengindikasikan bahwa adanya suatu sistem panas bumi yang terbentuk di bawah permukaan bumi yang diakibatkan oleh adanya aktifitas geologi, seperti vulkanisme dan tektonisme yang kemudian mengakibatkan air di bawah permukaan mengalami pemanasan, kemudian muncul di permukaan sebagai mata air panas. Salah satu aspek pendekatan yang dilakukan dalam penelitian ini adalah 
mencoba meneliti karakteristik sistem reservoir panas bumi daerah penelitian berdasarkan data karakteristik mata air panas. Pengklasifikasian tipe-tipe fluida sumber mata air panas bertujuan untuk mengetahui pemanfaatan dari masing-masing sumber mata air panas berdasarkan tipe fluidanya.

Berdasarkan penelitian yang telah dilakukan pada tahun 2003 oleh Munandar, dkk, tidak dilakukan pengklasifikasian karakteristik reservoir berdasarkan tipe fluida mata air panas di daerah Gunung Talang. Berdasarkan permasalahan tersebut dan merujuk pada penelitian-penelitian sebelumnya perlu dilakukan penelitian serupa di daerah panas bumi Gunung Talang. Penelitian ini juga dilakukan karena masih kurangnya pemanfaatan yang dilakukan atau kurang maksimalnya pemanfaatan dari sistem panas bumi tersebut, sehingga dari data yang diperoleh bisa diketahui pemanfaatan secara optimal dari masingmasing mata air panas yang akan diuji, apakah sebagai sumber energi, pertanian dan sebagai lokasi objek wisata.

\section{METODE}

Pada penelitian ini bahan yang digunakan adalah air panas yang berasal dari lima sumber mata air panas di Kecamatan Gunung Talang, Kabupaten Solok (Gambar 1). Sedangkan bahan tambahan yang digunakan dalam pengujian sampel adalah larutan $\mathrm{H}_{2} \mathrm{SO}_{4}$, kristal $\mathrm{BaCl}_{2}$ dan larutan salt acid sebagai reagen. Alat-alat yang digunakan dalam penelitian ini antara lain : $\mathrm{pH}$ meter, spektrofotometer, dan konduktivitimeter.

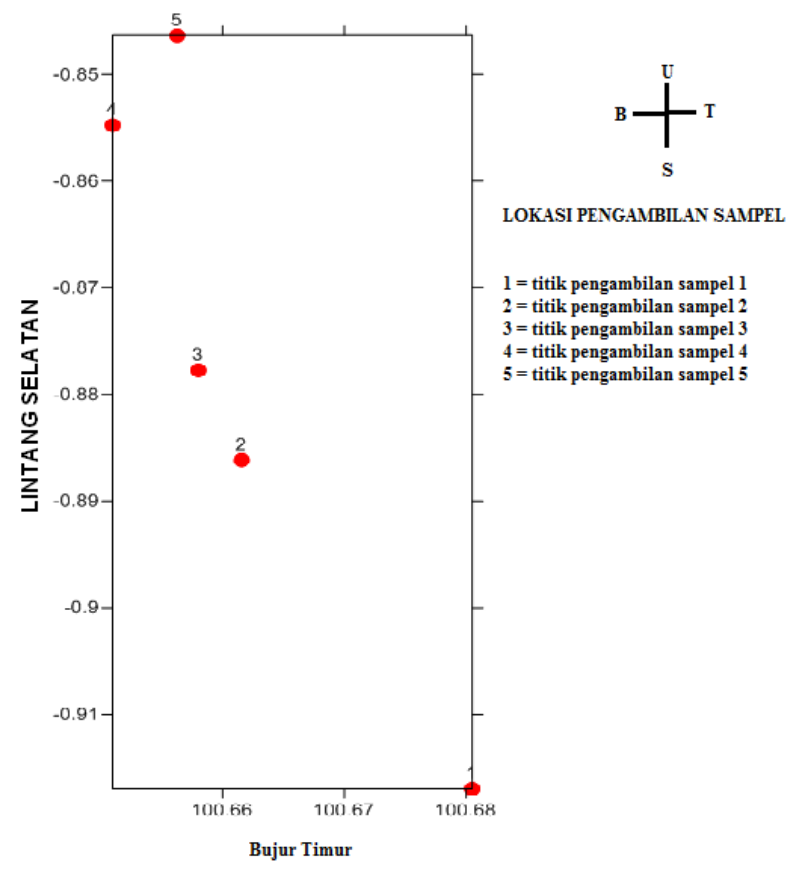

Gambar 1 Lokasi pengambilan samper berdasarkan koordinat GPS

\subsection{Uji Kandungan $\mathrm{SO}_{4}{ }^{2-}$}

Untuk menguji kandungan ion $\mathrm{SO}_{4}{ }^{2-}$ digunakan alat spektrofotometer merk cole parmer tipe 1100 RS. Metode yang digunakan pada pengujian ini adalah metode spektofotometri. Metode ini dilakukan dengan langkah-langkah sebagai berikut : 
1. Larutan standar dibuat dengan konsentrasi $10,20,30,40$, dan 50 ppm dengan cara menambahkan larutan salt acid dan kristal $\mathrm{BaCl}_{2}$ yang kemudian diaduk menggunakan mixer selama 5 menit. Untuk sampel diberi perlakuan sama dengan larutan standar.

2. Larutan standar yang telah dibuat kemudian diukur absorbansinya dengan menggunakan spektrofotometer.

3. Hasil yang didapatkan kemudian diplot ke dalam kurva.

4. Selanjutnya sampel diukur nilai absorbansinya.

5. Hasil yang di dapatkan kemudian dihubungkan dengan persamaan kurva yang telah diplot berdasarkan nilai absorbansi larutan standar. Persamaan yang digunakan adalah Persamaan 1

$$
\mathrm{y}=\mathrm{ax}+\mathrm{b}
$$

dimana $y$ adalah nilai absorbansi, $a$ adalah gradien garis, dan $x$ adalah kandungan ion $\mathrm{SO}_{4}{ }^{2-}$.

\subsection{Uji Kandungan $\mathrm{Cl}^{-}$}

Langkah pertama untuk menentukan nilai kandungan $\mathrm{Cl}^{-}$adalah dengan menguji nilai konduktivitas listriknya terlebih dahulu. Sampel diuji dengan mencelupkan elektroda ke dalam larutan aquades, kemudian ditunggu hingga angka pada konduktivitimeter menunjukkan angka nol. Konduktivitas diukur pada suhu $25^{\circ} \mathrm{C}$.

Setelah nilai konduktivitas listriknya diketahui, selanjutnya untuk menentukan kadar klorida dalam sampel mata air panas digunakan hubungan antara konsentrasi klorida dan konduktivitas listrik. Untuk rentang nilai konduktivitas listrik yang lebih besar $(0,15$ sampai $40 \mathrm{dSm}^{-1}$ ) persamaan yang digunakan adalah model pangkat yaitu menggunakan Persamaan 2.

$$
C l=2,12,1 E C^{14}
$$

dengan $\mathrm{Cl}$ adalah konsentrasi klorida $\left(\mathrm{molm}^{-3}\right)$ dan $E C$ adalah konduktivitas listrik ( $\mathrm{dSm}^{-}$ 1) (Abyaneh, 2005).

\subsection{Uji Kandungan $\mathrm{HCO}_{3}^{-}$}

Untuk menentukan kadar $\mathrm{HCO}_{3}{ }^{-}$dalam sampel mata air panas dilakukan dengan metode titrasi asam basa. Sampel dimasukkan ke dalam gelas beker sebanyak $100 \mathrm{~mL}$. pH meter dimasukkan ke dalam gelas beker, kemudian dititrasi dengan larutan $\mathrm{H}_{2} \mathrm{SO}_{4}$ sampai $\mathrm{pH}$ 4,5. Volume $\mathrm{H}_{2} \mathrm{SO}_{4}$ yang terpakai dalam proses titrasi dicatat. Kadar $\mathrm{HCO}_{3}{ }^{-}$dihitung dengan Persamaan 3.

$$
\mathrm{HCO}_{3}^{-}=\frac{A \times N \times 50000}{W}
$$

dengan $A$ adalah volume larutan $\mathrm{H}_{2} \mathrm{SO}_{4}$ yang terpakai pada proses titrasi, $N$ adalah normalitas $\mathrm{H}_{2} \mathrm{SO}_{4}$, dan $V$ adalah volume sampel (Gusnidar, 2012).

\section{HASIL DAN DISKUSI}

\subsection{Hasil Uji Kandungan Ion Sulfat $\left(\mathrm{SO}_{4}{ }^{2-}\right)$, Bikarbonat $\left(\mathrm{HCO}_{3}{ }^{-}\right)$, dan $\mathrm{Klorida}\left(\mathrm{Cl}^{-}\right)$}

Dari uji laboratorium dan pengolahan data yang telah dilakukan didapatkan nilai untuk kandungan ion untuk masing-masing lokasi seperti yang ditunjukkan pada Tabel 1. 
Tabel 1 Nilai kandungan ion sulfat, bikarbonat, dan klorida

\begin{tabular}{|c|c|c|c|}
\hline Lokasi & $\begin{array}{c}\text { Sulfat } \\
(\mathbf{m g} / \mathbf{L})\end{array}$ & $\begin{array}{c}\text { Bikarbonat } \\
(\mathbf{m g} / \mathbf{L})\end{array}$ & $\begin{array}{c}\text { Klorida } \\
(\mathbf{m g} / \mathbf{L})\end{array}$ \\
\hline 1 & 121,88 & 42,00 & 6,11 \\
\hline 2 & 193,75 & 90,30 & 6,28 \\
\hline 3 & 80,00 & 48,30 & 6,25 \\
\hline 4 & 133,13 & 89,25 & 6,24 \\
\hline 5 & 178,74 & 111,30 & 6,28 \\
\hline
\end{tabular}

Dari Tabel 1 dapat dilihat bahwa nilai kandungan ion sulfat merupakan kandungan tertinggi dari ion lainnya dengan rentang nilai antara 80,00 - 193,75 mg/L, diikuti oleh nilai kandungaan ion bikarbonat dengan rentang nilai $42-111,30 \mathrm{mg} / \mathrm{L}$ dan selanjutnya diikuti oleh kandungan ion klorida dengan rentang nilai $6,11-6,28 \mathrm{mg} / \mathrm{L}$ sebagai nilai kandungan ion terendah.

\subsection{Tipe Mata Air Panas}

Untuk menentukan tipe mata air panas dari masing-masing sampel yang telah diuji digunakan diagram trilinier yang berfungsi untuk mengetahui tipe mata air panas berdasarkan pada nilai kandungan ion sampel yang telah diketahui sebelumnya. Gambar 2 merupakan hasil plotting dari kelima sumber mata air panas menggunakan diagram trilinier berdasarkan kandungan ion dari masing-masing sampel.

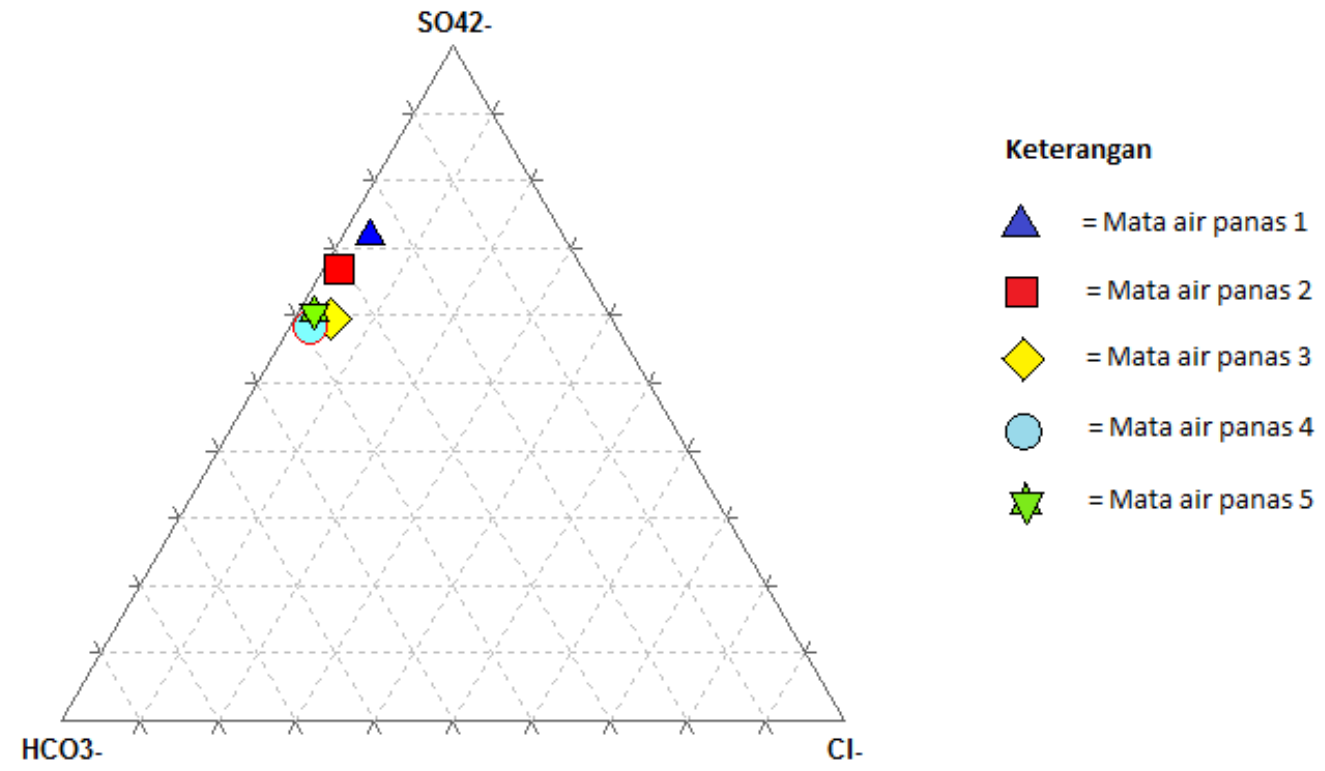

Gambar 2 Diagram trilinier untuk kelima sumber mata air panas

Berdasarkan hasil pengujian nilai kandungan ion mata air panas untuk sampel 1, didapatkan nilai kandungan sulfat sebesar $121,88 \mathrm{mg} / \mathrm{L}$, nilai kandungan bikarbonat sebesar 42,00 mg/L, dan nilai kandungan klorida sebesar $6,11 \mathrm{mg} / \mathrm{L}$. Dari diagram trilinier dapat ditentukan bahwa tipe mata air panas sampel 1 adalah bertipe air sulfat.

Untuk mata air panas di lokasi 2 nilai kandungan sulfat adalah sebesar 193,75 mg/L, nilai kandungan bikarbonat 90,30 mg/L, dan nilai kandungan klorida 6,28 mg/L. Setelah nilai dari masing-masing kandungan ion dimasukkan ke dalam diagram trilinear didapatkan hasil yaitu mata air panas lokasi 2 bertipe air sulfat. 
Pada mata air panas lokasi 3 nilai kandungan sulfat masih merupakan kandungan ion tertinggi di antara dua ion lainnya dengan nilai kandungan sebesar $80,00 \mathrm{mg} / \mathrm{L}$, diikuti nilai kandungan bikarbonat sebesar 48,30 mg/L, dan nilai kandungan klorida sebesar 6,25 $\mathrm{mg} / \mathrm{L}$. Dari pembacaan diagram trilinear diketahui bahwa mata air panas lokasi 3 juga merupakan mata air panas bertipe sulfat.

Pada mata air panas lokasi 4 didapatkan nilai kandungan sulfat sebesar 133,13 mg/L, nilai kandungan bikarbonat sebesar 89,25 mg/L, dan nilai kandungan klorida sebesar 6,24 $\mathrm{mg} / \mathrm{L}$. Dari diagram trilinier dapat ditentukan bahwa tipe mata air panas sampel 4 adalah bertipe air sulfat.

Berdasarkan hasil pengujian nilai kandungan ion mata air panas untuk sampel 5, didapatkan nilai kandungan sulfat sebesar $133,13 \mathrm{mg} / \mathrm{L}$, nilai kandungan bikarbonat sebesar 89,25 mg/L, dan nilai kandungan klorida sebesar 6,24 mg/L. Dari diagram trilinier dapat ditentukan bahwa tipe mata air panas sampel 5 adalah bertipe air sulfat.

\subsection{Analisis Mata Air Panas Bertipe Sulfat}

Dari hasil penelitian yang telah dilakukan dan setelah nilai kandungannya dimasukkan ke dalam diagram trilinear dapat diketahui bahwa kelima mata air panas di daerah Gunung Talang Kabupaten Solok bertipe air sulfat (Gambar 2). Air panas yang bertipe sulfat merupakan fluida yang terbentuk pada kedalaman dangkal dan terbentuk sebagai akibat dari proses kondensasi gas panas bumi yang menuju dekat permukaan. Gas panas bumi, dengan kandungan gas dan volatilnya seperti air dan karbon dioksida, pada dasarnya larut dalam kandungan fluida yang terletak pada zona yang dalam tetapi terpisah dari air klorida (Ariwibowo dan Nurrohman, 2012).

Air sulfat biasanya ditemukan pada batas daerah dan berjarak tidak jauh dari area upflow utama. Jika dilihat dari topografi, maka lokasi pastinya terletak jauh di atas water table dan di sekeliling boiling zone, walaupun kebanyakan juga sering ditemukan di dekat permukaan (pada kedalaman $<100 \mathrm{~m}$ ). Air sulfat dapat mengalir melewati patahan (fault) menuju sistem panas bumi. Pada lokasi inilah, air sulfat dipanaskan, kemudian air sulfat ikut mempengaruhi alterasi batuan dan bercampur dengan air klorida. Air panas sulfat ditandai dengan tingginya kandungan $\mathrm{H}_{2} \mathrm{~S}$, kandungan air panas sulfat sangat bervariasi karena berasal dari oksidasi hidrogen sulfida dalam zona vadose. Air panas sulfat merupakan campuran dari gas vulkanik (mengandung $\mathrm{H}_{2} \mathrm{~S}$ ) bertemperatur rendah bersama dengan air permukaan dan air meteorik/bawah permukaan (Hantono, dkk., 2001).

Air jenis ini dapat diinterpretasikan sebagai air hasil pemanasan oleh uap (steam heated water). Oleh karena air jenis sulfat yang dihasilkan oleh proses pemanasan uap ini sudah melarutkan batuan samping selama perjalanannya sampai keluar sebagai mata air, maka air jenis ini tidak mewakili komposisi air reservoir secara keseluruhan (Wahyudi, 2005). Manifestasi geotermal yang memiliki konsentrasi sulfat tinggi biasanya terdapat pada wilayah yang tinggi dan dekat dengan wilayah vulkanik (Fornier, 1981 dalam Fitrianty, 2012). Posisi lima titik air panas di lokasi penelitian ini yang berada di wilayah vulkanik mendukung terbentuknya air panas bertipe sulfat.

Daerah panas bumi gunung talang mempunyai delapan satuan batuan dengan urutan dari tua ke muda yaitu Satuan Batuan Malihan, Satuan Batuan Vulkanik Tua, Satuan Batuan Lava Bukit Kili, Satuan Batuan Lava Bukit Bakar, Satuan Batuan Lahar Bukit Bakar, Satuan Batuan Lahar Gunung Talang, Endapan Danau, Dan Endapan Permukaan. Mata air panas di Kecamatan Gunung Talang keluar melalui rekahan - rekahan vulkanik muda, dimana batuan di daerah tersebut terletak pada satuan batuan Lahar Bukit Bakar. Batuan pada Lahar Bukit Bakar tersusun oleh bahan vulkanik yang tak terpisahkan yang terdiri dari piroklastik dan lava andesitik. Batuan piroklastik dan lava andesit ini termasuk 
kedalam jenis batuan beku. Mata air panas bertipe sulfat memiliki tingkat keasaman yang tinggi hal ini dapat terjadi akibat batuan bekunya bersifat asam karena kandungan silika yang tinggi. Pada perjalanannya ke permukaan mata air panas tersebut dapat melarutkan batuan beku yang bersifat asam tersebut sehingga menghasilkan mata air panas bertipe sulfat. Mata air panas bertipe sulfat juga mengindikasikan tinggi nya kandungan gas $\mathrm{H}_{2} \mathrm{~S}$ pada batuan tersebut, hal ini dapat terjadi karena gas $\mathrm{H}_{2} \mathrm{~S}$ dilepaskan saat mata air panas keluar melalui rekahan batuan beku tersebut. Karena pada daerah penelitian memiliki satuan batuan yang hegemoni, maka semua lokasi penelitian memiliki tipe mata air yang sama yaitu bertipe mata air sulfat (Kholid dan Marpaung, 2011).

Mata air panas di daerah penelitian memiliki kandungan yang hampir sama dengan mata air panas di daerah Simusuh Kabupaten Pasaman yaitu didominasi oleh sulfat (Dwitama, 2013). Hal ini mengindikasikan pada kedua daerah di Sumatera Barat ini terdapat persamaan jenis fluida mata air panas, dan diperkirakan karakteristik dari kedua reservoir yaitu kedalaman dan suhu hampir sama.

\section{KESIMPULAN}

Dari hasil pengujian kandungan ion $\mathrm{HCO}_{3}{ }^{-}, \mathrm{SO}_{4}{ }^{2-}$, dan $\mathrm{Cl}^{-}$mata air panas di Kecamatan Gunung Talang, dan dengan menggunakan diagram triliner, maka lima titik mata air panas tersebut memiliki tipe fluida sulfat, dengan kandungan sulfat antara $80,00 \mathrm{mg} / \mathrm{L}$ sampai 193,75 mg/L. Dari hasil ini dapat disimpulkan bahwa sistem reservoir dari kelima sumber mata air panas yang terbentuk akibat sistem vulkanik aktif mempunyai karakteristik berkedalaman sedang. Sistem reservoir yang memiliki kandungan ion sulfat yang tinggi juga mengindikasikan bahwa reservoir memiliki suhu bertipe sedang yaitu antara $125{ }^{\circ} \mathrm{C}$ sampai $225{ }^{\circ} \mathrm{C}$. Hal ini sesuai dengan teori yang dikemukakan oleh Hochstein, 1990 (dalam Saptadji, 2009).

\section{DAFTAR PUSTAKA}

1. Abyaneh, dkk., 2005, Chloride Estimation in Ground Water From Electrical Conductivity Measurement, College of Agriculture, Volume 11, No. 1, Bu-Ali Sina University,Iran.

2. Ariwibowo, Y. dan Nurrohman, H., 2012, Studi Geokimia Air Panas Daerah Prospek Panas Bumi Gunung Kendalisada, Kabupaten Semarang, Provinsi Jawa Tengah, Teknik, Volume 33, No. 1, Universitas Diponegoro.

3. Dwitama, E. P, 2013, Karakteristik Geokimia Panas Bumi Berdasarkan Data Air Panas Daerah Simisuh, Kabupaten Pasaman Provinsi Sumatera Barat. Skripsi, Fakultas Teknik Geologi, Universitas Padjadjaran, Bandung.

4. Fitrianty, U., 2012, Sebaran Mata Air Panas Di Kabupaten Serang, skripsi, Fakultas Matematika Dan Ilmu Pengetahuan Alam, Universitas Indonesia, Depok.

5. Gusdinar, T., 2012, Titrasi Asam Basa (Titrasi Netralisasi), Sekolah farmasi Institut Teknologi Bandung, Bandung.

6. Hantono, dkk., 2001, Studi Geokimia Fluida Panas Bumi Daerah Prospek Panas Bumi Nglimut, Gunung Ungaran Kecamatan Limbang, Kabupaten Kendal, Jawa Tengah, Teknik, Volume 32, No.3, Universitas Diponegoro.

7. Kholid, M., dan Marpaung, H., 2011, Survei Megnetotellurik daerah Panas Bumi Bukit Kili Gunung Talang, Kabupaten Solok, Sumatera Barat, Prosiding Hasil Kegiatan Pusat Sumber Daya Geologi.

8. Munandar, A, 2003, Penyelidikan Terpadu Daerah Panas Bumi Gunung Talang Kabupaten Solok-Sumatera Barat, SUBDIT Panas Bumi, Departemen Sumber Daya Mineral, Jakarta. 
9. Saptadji, N. M, 2009, Karakteristik Reservoir Panas Bumi, Geothermal ITB, Institut Teknologi Bandung, Bandung.

10. Wahyudi, 2005, Kajian Potensi Panas Bumi Dan Rekomendasi Pemanfaatannya Pada Daerah Prospek Gunungapi Ungaran Jawa Tengah, Skripsi, Fakultas Matematikan dan Ilmu Pengetahuan Alam, Universitas Gajah Mada, Yogyakata. 